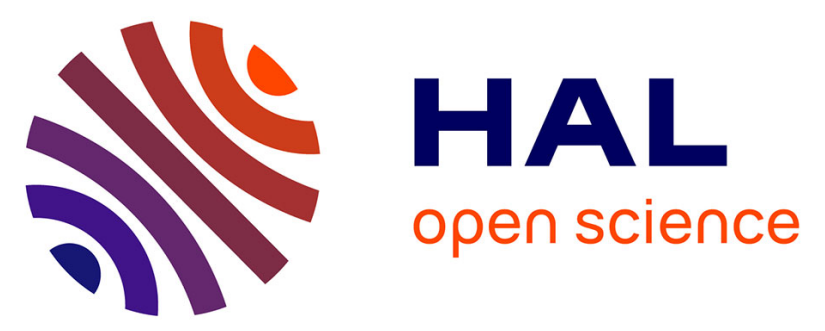

\title{
The Salmonella pathogenicity island 1 and Salmonella pathogenicity island 2 type III secretion systems play a major role in pathogenesis of systemic disease and gastrointestinal tract colonisation of Salmonella enterica serovar Typhimurium in the chicken
}

\author{
Paul Wigley
}

\section{To cite this version:}

Paul Wigley. The Salmonella pathogenicity island 1 and Salmonella pathogenicity island 2 type III secretion systems play a major role in pathogenesis of systemic disease and gastrointestinal tract colonisation of Salmonella enterica serovar Typhimurium in the chicken. Avian Pathology, 2007, 36 (03), pp.199-203. 10.1080/03079450701264118 . hal-00540074

\author{
HAL Id: hal-00540074 \\ https://hal.science/hal-00540074
}

Submitted on 26 Nov 2010

HAL is a multi-disciplinary open access archive for the deposit and dissemination of scientific research documents, whether they are published or not. The documents may come from teaching and research institutions in France or abroad, or from public or private research centers.
L'archive ouverte pluridisciplinaire HAL, est destinée au dépôt et à la diffusion de documents scientifiques de niveau recherche, publiés ou non, émanant des établissements d'enseignement et de recherche français ou étrangers, des laboratoires publics ou privés. 


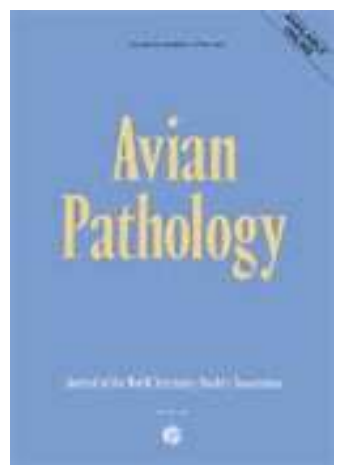

The Salmonella pathogenicity island 1 and Salmonella pathogenicity island 2 type III secretion systems play a major role in pathogenesis of systemic disease and gastrointestinal tract colonisation of Salmonella enterica serovar Typhimurium in the chicken

\begin{tabular}{|r|l|}
\hline Journal: & Avian Pathology \\
\hline Manuscript ID: & CAVP-2006-0191.R1 \\
\hline Manuscript Type: & Original Research Paper \\
\hline Date Submitted by the \\
Author: & 17-Jan-2007 \\
\hline Complete List of Authors: & Wigley, Paul; University of Liverpool, Veterinary Pathology \\
\hline Keywords: & Salmonella, Chicken, Type III secretion, SPI2 \\
\hline \multicolumn{2}{|}{} \\
\hline
\end{tabular}

\section{SCHOLARONE ${ }^{m}$}

Manuscripts 


\section{Cavp-2006-0191.R1}

The Salmonella pathogenicity island 1 and Salmonella pathogenicity island 2 type III secretion systems play a major role in pathogenesis of systemic disease and gastrointestinal tract colonisation of Salmonella enterica serovar Typhimurium in the chicken

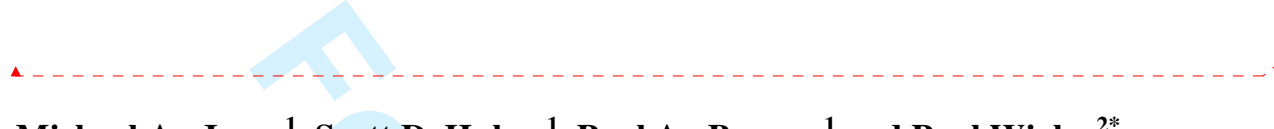

Michael A., Jones ${ }^{1}$, Scott D. Hulme ${ }^{1}$, Paul A., Barrow ${ }^{1}$ and Paul Wigley ${ }^{2 *}$

Short title: $(-$

${ }^{1}$ School of Veterinary Medicine and Science, University of Nottingham, Sutton Bonnington Campus, Loughborough, UK

${ }^{2}$ National Centre for Zoonoses Research, Department of Veterinary Pathology \& School of Infection and Host Defence, Univeristy of Liverpool, Leahurst, Neston,

CH64 7TE, UK $\Delta$

* Corresponding Author,

Email:paul.wigley@liv.ac.uk

Tel: $44(0) 1517946193$

Received 20 December 2006
Formatted: Right

Formatted: Font: $14 \mathrm{pt}$, Complex Script Font: $14 \mathrm{pt}$

Formatted: Font: Bold

Formatted: Font: Bold, Not

Superscript/ Subscript

Deleted: ${ }^{\pi}$

II

Formatted: Font: Italic
Formatted: Font: Italic

Formatted: Left

Formatted: Font: Italic 
The Salmonella pathogenicity island 1 and Salmonella pathogenicity island 2 type

III secretion systems play a major role in pathogenesis of systemic disease and gastrointestinal tract colonisation of Salmonella enterica serovar Typhimurium in the chicken

\section{$\underline{\text { Michael A., Jones }}{ }^{1}$, Scott D. Hulme ${ }^{1}$, Paul A., Barrow ${ }^{1}$ and Paul Wigley ${ }^{2 *}$}

\section{Abstract}

Salmonella enterica serovar Typhimurium infection of chickens is a major public and animal health problem. In young chicks $S$. Typhimurium infection results in severe systemic infection, in older chicks infection results in prolonged gastrointestinal tract colonisation. Here we determined the role of the Salmonella pathogenicity island 1 (SPI-1) and 2 (SPI-2) type III secretion systems (TTSS) in systemic infection and gastrointestinal tract colonisation of the chicken though experimental infection of chicks with a $S$. Typhimurium strain with mutations in the genes encoding the secretion system machinery of SPI-1 (spaS) and SPI-2 (ssaU) that prevent secretion of effector proteins.

In one-day-old chicks mutation of SPI-2 lead to a decrease in both systemic Deleted: Formatted: Indent: First line: $36 \mathrm{pt}$ bacterial numbers and pathology, though no difference in gastrointestinal numbers was observed. Mutation of SPI-1 had little effect in one-day old chicks. In oneweek-old animals the SPI-2 mutants could not be detected systemically and colonised the gastrointestinal tract only in low numbers in comparison to the parent strain and was cleared in one week. The SPI-1 mutant showed greatly reduced 
levels of systemic infection, and colonised the gastrointestinal tract at a lower level than the parent strain.

The findings show that the SPI-2 TTSS is required for systemic $S$.

Typhimurium infection in both infection models, and that it plays a significant role in gastrointestinal colonisation. The SPI-1 system is involved in both systemic Deleted: has infection and gastrointestinal colonisation, but does not appear absolutely essential for either infection process. 


\section{Introduction}

Salmonella enterica serovar Typhimurium is a major cause of food-borne zoonotic gastroenteritis. Consumption of contaminated poultry meat has been implicated as a major vehicle for the transmission of salmonellosis to man (Mead et al., 1999, Humphrey 2006). S. Typhimurium is able to colonise the gastrointestinal tract of chicken of a few days of age without clinical disease, with high numbers of Deleted: more than Deleted: old Deleted: in the Salmonella located within the caeca. These may be shed in faeces leading to horizontal transmission within broiler chicken flocks and eventually lead to contamination of meat particularly during the slaughter and production process. In newly hatched chicks $S$. Typhimurium infection causes systemic disease with widespread inflammation and pathology of the liver, spleen and gastrointestinal tract resulting in a high mortality rate in chicks (Withanage et al., 2004). In contrast birds of 1 week of age, only develop a limited systemic infection, though their Deleted: Deleted: Deleted: in gastrointestinal tract may remain colonised for many weeks_(Withanage et al., 2005).

Deleted: $q$

Although the virulence factors of $S$. Typhimurium infection in mice and

cattle have been widely studied, our understanding of their role in the chicken is relatively poor (Wallis \& Galyov, 2000). Previous studies have indicated that genes involved in the biosynthesis of lipopolysaccharide are required for both colonisation and systemic infection (Morgan et al., 2004; Turner et al., 1998) and that a number of outer membrane, metabolic and fimbrial genes are also required for colonisation (Morgan et al., 2004; Turner et al., 1998). Flagella are also involved in the initial stages of infection (Iqbal et al., 2005). Whilst the role Salmonella enterica pathogenicity islands 1 and 2 (SPI-1 and SPI-2) have been well described in mammals (Hensel, 2000; Shea et al., 1996; Wallis \& Galyov, 2000), their role is 
less clear in Typhimurium infection of chickens. We have previously shown that the SPI-2 system is required for virulence of the avian-specific Salmonella serovars Gallinarum and Pullorum (Jones et al., 2001; Wigley et al., 2002), though the role of the individual effector proteins are not understood. Individual genes of both SPI1 and SPI-2 have been identified as having a role in colonisation of the chicken gastrointestinal tract in large screening experiment of transposon mutants or in signature-tagged mutagenesis, though neither study indicated a major role in the colonisation process (Morgan et al., 2004; Turner et al., 1998). In this and our previous studies we have constructed strains with mutations in the genes spaS and $s s a U$, that encode major structural components of the SPI-1 and SPI-2 type III secretion (TTSS) systems respectively (Jones et al., 1998; Jones et al., 2001; Wigley et al., 2002; Wood et al., 2000). This approach has the advantage of eliminating the ability of the secretion system to translocate proteins to the host whilst not disrupting the function of other genes within the pathogenicity island.

We used two different chicken infection models to determine the role TTSS in both systemic disease and during asymptomatic caecal colonisation.

To determine the role of the two TTSS systems in systemic disease we used the one-day-old chick model (Withanage et al., 2004) and compared the bacterial numbers and gross pathology at post mortem to bacterial counts and pathology of the mutant strains over the first 72 hours following infection.

To determine the role of the two TTSS systems in colonisation we used a oneweek-old chicken infection model. These birds do not develop clinical disease but remain colonised for several weeks (Withanage et al., 2005) . The bacteriology and pathology of parent and mutant strains was followed at time points up to two weeks post infection. 
These two in vivo studies allowed us to determine not only whether there is

Formatted: Indent: First line: $36 \mathrm{pt}$ presence or absence of the mutant as in previous studies (Morgan et al., 2004) but also to quantify any reduction in numbers infecting or colonising the chicken.

\section{Materials and methods}

Bacterial strains. Salmonella enterica serovar Typhimurium F98 is well defined for its ability to cause disease and colonise the gastrointestinal tract of chickens (Smith \& Tucker, 1975; Withanage et al., 2004; Withanage et al., 2005) . A spontaneous nalidixic acid resistant strain of F98 was used for these studies. Mutations in the spaS and ssaU genes, the product of which is part of the secretory machinery of the SPI-1 and SPI-2 systems respectively, were produced through insertion of the suicide plasmids pSS1 and pSS2 as previously described (Jones et al., 1998; Jones et al., 2001; Wigley et al., 2002; Wood et al., 2000). All strains were grown from stocks maintained at $-70^{\circ} \mathrm{C}$ in Luria Bertani (LB) broth supplemented with $30 \%$ (v/v) glycerol. Bacteria were cultured for $18 \mathrm{~h}$ in LB broth at $37^{\circ} \mathrm{C}$ in an orbital shaking incubator at $150 \mathrm{rpm}$.

-

Experimental animals. One-day-old specific-pathogen free Rhode Island Red chicks were obtained from the Poultry Production Unit, Institute for Animal Health, Compton, United Kingdom. Birds were maintained in wire cages at an ambient temperature of $30^{\circ} \mathrm{C}$ which was reduced to $20^{\circ} \mathrm{C}$ at one week of age. Birds were given ad libitum access to water and to vegetable protein-based feed (SDS, Witham, Essex, United Kingdom).

Deleted: II

Infection of one-day-old chicks 
Infection of one day old chicks. Sixty one-day old chicks were divided into four equal groups then infected orally with $\log _{10} 8 \mathrm{cfu}$ of S. Typhimurium F98, spaS mutant strain, ssaU mutant strain or mock infected with LB broth. At 24,48 at $72 \mathrm{~h}$ post infection five birds from each group were killed for post mortem analysis. At post mortem samples of liver and caecal contents were removed aseptically and bacteriological analysis performed as previously described (Barrow \& Lovell, 1991). Samples were plated onto Brilliant Green agar (Oxoid, Unipath, Basingstoke, Hants, United Kingdom) and then incubated at $37^{\circ} \mathrm{C}$ for $18 \mathrm{~h}$. All bacteria were assessed for maintenance of their insertion mutations through maintenance of antibiotic resistance encoded on the insert and were found to be stable during these in vivo studies. Variation between groups was determined by analysis of variance (ANOVA).

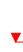

$\underline{\text { Infection of one week old birds. Eighty one-day-old chickens were given } 0.2 \mathrm{ml} \text { of }}$ an adult gut flora preparation orally to minimise variation in gut flora between animals (Barrow et al., 2004), then divided into four groups. When the birds reached one week of age they were infected orally with $1 \times 10^{8}$ cfu of $S$. Typhimurium F98, spaS mutant strain, ssaU mutant strain or mock infected with LB broth. At 1, 3, 7 and 14 days post infection five birds from each group were killed for post mortem analysis. Samples were taken and processed as described above.

\section{Results}


Infection of one day old birds. At post mortem birds infected with $S$. Typhimurium F98 began to show signs at systemic infection by $24 \mathrm{~h}$ post infection, with birds showing hepatosplenomegaly. By $48 \mathrm{~h}$ post infection this was pronounced, along with haemorrhaging of the intestine and bloody caecal contents. Hepatosplenomegaly was also seen in birds infected with the spaS mutant at $48 \mathrm{~h}$ post infection, with haemorrhage and bloody caecal contents found at $72 \mathrm{~h}$ post infection. The birds infected with the ssaU mutant did not show any increased pathology over the control group. In the liver all the infected groups showed similar bacterial counts at $24 \mathrm{~h}$ post infection, which initially dropped at $48 \mathrm{~h}$ but rose again by $72 \mathrm{~h}$ (Figure 1a). At $72 \mathrm{~h}$ post infection both the parent and spaS strains showed bacterial counts in excess of $10^{5} \mathrm{cfu} / \mathrm{g}$, whereas the $s s a U$ infected group showed a significant $(\mathrm{P}=0.007)$ reduction in bacterial numbers to the spaS or parent strain.

All strains showed similar levels of Salmonella in the caecal contents, with Formatted: Indent: First line: $36 \mathrm{pt}$ counts around $10^{8} \mathrm{cfu} / \mathrm{g}$ found at $72 \mathrm{~h}$ post infection (Figure $1 \mathrm{~b}$ ). No pathology was recorded in the control group, nor any Salmonella recovered at any time point.

$=$

Infection of one week old birds. Following infection of one week old birds only limited pathology, mild to moderate hepatopslenomegaly, was seen in the parent strain-infected group and to a lesser extent the spaS infected group. No pathology was seen in the ssaU infected group. Salmonella was detected in the liver of birds infected with the parent strain from $3 \mathrm{~d}$ post infection onwards, which declined until the end of the experiment (Figure 2a). The spaS strain was detected in the liver at three days post infection at significantly lower levels than the parent strain 
$(\mathrm{P}=0.004)$, and was cleared by seven days post infection. The $s s a U$ strain was not detected in the liver throughout the experiment.

All three strains were detected in the caecal contents at one and three days post infection (Figure 2b), though at three days post infection both $\operatorname{spaS}(\mathrm{P}=0.002)$ and $s s a U(\mathrm{P}=0.003)$ were at significantly lower numbers than the parent strain. At seven and 14 days post infection both the parent strain and spaS strains continued to colonise the caeca, the spaS strain at lower, though not statistically significant, numbers than the parent. In contrast the $s s a U$ mutant strain could not be detected in the caecal contents at either seven or $14 \mathrm{~d}$ post infection. No pathology was recorded in the control group, nor any Salmonella recovered at any time point.

\section{Discussion}

We wanted to investigate the role of the TTSS in both colonisation and systemic disease of poultry by $S$. Typhimurium.

The role of SPI-1 in the induction of gastroenteritis is well documented

(Wallis et al., 1999), though its exact role in systemic disease is less clearly defined. Previous studies have indicated that systemic disease can progress through a SPI-1 independent manner in mice and poultry with $S$. Typhimurium and $S$. Gallinarum respectively (Jones et al., 2001; Shea et al., 1996; Shea et al., 1999). However there is some evidence that SPI-1 contributes to disease in poultry during S. Pullorum infection (Wigley et al., 2002). In this study while SPI-1 TTSS is not essential in the initial stages of systemic infection in one-day-old birds (24h; Figure 1a) it clearly has a role to play in the establishment of systemic infection with a drop in counts at 48 hours post infection. The role of SPI-1 in S. Typhimurium systemic 
disease of poultry of one-week-old birds is clearly demonstrated by difference in liver counts between the parent and spaS mutant strain(figure 2a).

The role of SPI-2 in systemic and intracellular survival has been well documented (Bispham et al., 2001; Jones et al., 2001; Shea et al., 1999) but a role for SPI-2 in colonisation of the intestine is not obvious. The data presented here indicates that SPI-2 TTSS is not only required by $S$. Typhimurium in systemic infection poultry but also play a role in colonisation of the gastrointestinal tract.

This role of the SPI-2 system in systemic Typhimurium disease is perhaps not surprising, given its essential role in systemic infection of the chicken by both $S$. Gallinarum and S. Pullorum (Jones et al., 2001; Wigley et al., 2002) and given the weight of evidence in the literature that he SPI-2 TTSS plays a major role in intracellular survival within macrophages and is essential for virulence in mice infected with S. Typhimurium (Chakravortty et al., 2002; Cirillo et al., 1998; Hensel, 2000; Shea et al., 1996; Shea et al., 1999). There is considerable attenuation of pathology and bacterial numbers recovered form the liver of the $s s a U$ infected birds. This is particularly pronounced in one-week-old birds where ssaU strain shows complete attenuation. The difference between the infection models may reflect a more developed and responsive innate immune response in one-weekold chickens compared to the day-old-birds.

The requirement for the SPI-2 system in gastrointestinal colonisation is perhaps a little more surprising and may indicate a lack of understanding of all the components of colonisation process in this field of research. A large number of publications have been directed at identifying Salmonella components which are required for efficient colonisation. Bacteria have to survive a series of stressful environments including acid $\mathrm{pH}$, action of bile and antimicrobial peptides and 
decreasing oxygen tension to access their site of colonisation (Rychlik \& Barrow, 2005). These factors include those involved in adhesion; such as lipopolysaccharide and fimbrae, a range of metabolic genes and a number of regulatory genes which regulate these other components (Morgan et al., 2004; Rychlik \& Barrow, 2005; Turner et al., 1998). Early studies using random transposon mutagenesis have shown that the SPI-1 effector SipC plays some role in the colonisation of $S$. Typhimurium F98 in the chicken (Turner et al., 1998). Components of both SPI-1 and SPI-2 were also identified by signature tagged mutagenesis, as being required for colonisation of the gastrointestinal tract of calves but were shown to play a much less significant role in colonisation of chickens (Morgan et al., 2004). The role for SipC in colonisation is supported by this study. The differences between this study and that of Morgan et al., (Morgan et al., 2004) are interesting. While all the SPI-1 or SPI-2 genes screened in cattle were attenuated for colonisation, only 3 out of the 37 screened were attenuated for colonization in poultry and of those only one appeared fully attenuated. There was also some attenuation due to insertions in both TTSS- 1 and TTSS- 2 effector proteins. The signature tag study did not directly identify spaS or ssaU mutants but did include other mutants which would be predicted to block their secretion function, so there appears to be a differential in gene functions with these islands. It is also important point out that there are differences in $S$. Typhimurium strain, poultry line and experimental protocols used. In this study we used a quantitative approach by making counts of caecal contents, whereas the use of cloacal swabbing to determine colonization by Morgan et al., (2004) is rather more qualitative. In calves the SPI-2 system is involved in both systemic disease, induction of enteritis and colonisation (Bispham et al., 2001; Morgan et al., 2004). Cleary the results from Morgan et al. (Morgan et al., 2004) 
and this study indicate a role, albeit ill-defined, for components of SPI-2 TTSS in poultry colonisation.

The role of SPI-2 in colonisation is intriguing. The mutation in the $s s a U$ gene prevents formation of the SPI-2 machinery rather than prevent production of an effector protein, so it effectively abrogates the complete function of the TTSS. Therefore its disruption may have pleiotropic effects which may manifest in a poor colonisation. Therefore it is hard to define whether it is improved intracellular survival which is the main requirement from this system for colonisation. Nevertheless it is clear from this and other studies that secreted pathogenicity island encoded virulence factors, including Type II , Type III and Type V secretion systems are involved in colonisation of the chicken gastrointestinal tract (Morgan et al., 2004; Turner et al., 1998). This is indicative of a dynamic process by which Salmonella interacts with the host.

During colonisation $S$. Typhimurium can be observed attached to the Deleted: epithelium of the intestine and caeca (Hulme and Barrow unpublished). One may speculate that there is an interaction with host components and inhibition of their function may lead to the prolonged intestinal colonisation of S. Typhimurium found in chickens.

Whatever the role SPI-1 and SPI-2 TTSS of $S$. Typhimurium during infection and colonisation it is clear that they have a substantial impact on events during colonisation and systemic disease of poultry. 


\section{References}

Barrow, P. A. \& Lovell, M. A. (1991). Experimenatl infection of egg-laying hens Formatted: Indent: Before: $0 \mathrm{pt}$, Hanging: $28.35 \mathrm{pt}$, Line spacing: Double with Salmonella enteritidis phage type 4. Avian Pathology 2 20, 335-348.

Barrow, P. A., Bumstead, N., Marston, K., Lovell, M. A. \& Wigley, P. (2004). Faecal shedding and intestinal colonization of Salmonella enterica in in-bred chickens: the effect of host-genetic background. Epidemiology and Infection, $132,117-126$

Bispham, J., Tripathi, B. N., Watson, P. R. \& Wallis, T. S. (2001). Salmonella pathogenicity island 2 influences both systemic salmonellosis and Salmonella-induced enteritis in calves. Infection and Immunity $y_{2} 69,367-377$.

Chakravortty, D., Hansen-Wester, I. \& Hensel, M. (2002). Salmonella pathogenicity island 2 mediates protection of intracellular Salmonella from reactive nitrogen intermediates. Journal of Experimental Medicine ${ }_{2}$ 195, $1155-1166$

Cirillo, D. M., Valdivia, R. H., Monack, D. M. \& Falkow, S. (1998). Macrophagedependent induction of the Salmonella pathogenicity island 2 type III secretion system and its role in intracellular survival. Molecular Microbiology $30,175-188_{2}$

Hensel, M. (2000). Salmonella pathogenicity island 2. Molecular Microbiology ${ }_{2} 36$, 1015-1023,

Humphrey, T,J, (2006) Public health aspects of Salmonella enterica in food production . In P.Mastroeni \& D. Maskell (2006) Salmonella Infections: Clinical, Immunological and Molecular Aspects (pp.89-115). Cambridge UK: Cambridge University Press, 
Iqbal, M., Philbin, V. J., Withanage, G. S. Wigley, P., Beal, R. K., Goodchild, M. J., Barrow, P., McConnell, I., Maskell, D. J., Young, J., Bumstead, N., Boyd, Y.\& Smith, A. L. (2005). Identification and functional characterization of chicken toll-like receptor 5 reveals a fundamental role in the biology of infection with Salmonella enterica serovar typhimurium. Infection and Immunity $23,2344-2350$.

Jones, M. A., Wood, M. W., Mullan, P. B., Watson, P. R., Wallis, T. S. \& Galyov, E. E. (1998). Secreted effector proteins of Salmonella dublin act in concert to induce enteritis. Infection and Immunity $266,5799-5804$.

Jones, M. A., Wigley, P., Page, K. L., Hulme, S. D. \& Barrow, P. A. (2001).

Salmonella enterica serovar Gallinarum requires the Salmonella pathogenicity island 2 type III secretion system but not the Salmonella pathogenicity island 1 type III secretion system for virulence in chickens. Infection and Immunit $2 y$ $69,5471-5476$

Mead, P. S., Slutsker, L., Dietz, V., McCaig, L. F., Bresee, J. S., Shapiro, C.,

Griffin, P. M. \& Tauxe, R. V. (1999). Food-related illness and death in the United States. Emerging Infectious Disease 2 5, 607-625. Morgan, E., Campbell, J. D., Rowe, S. C., Bispham, J., Stevens, M. P., Bowen, A. J., Barrow, P. A., Maskell, D. J. \& Wallis, T. S. (2004). Identification of hostspecific colonization factors of Salmonella enterica serovar Typhimurium. Molecular Microbiology $y_{2}$ 54, 994-1010. Rychlik, I. \& Barrow, P. A. (2005). Salmonella stress management and its relevance to behaviour during intestinal colonisation and infection. FEMS Microbiology Reviews 29, 1021-1040.
Formatted: Font: Times New Roman, 12 pt, Complex Script Font: $12 \mathrm{pt}$

Formatted: Font: Times New Roman, 12 pt, Complex Script Font: $12 \mathrm{pt}$

Formatted: Font: Times New Roman, 12 pt, Complex Script Font: $12 \mathrm{pt}$

Formatted: Font: Times New Roman, 12 pt, Complex Script Font: $12 \mathrm{pt}$

Formatted: Font: Times New Roman, 12 pt, Complex Script Font: $12 \mathrm{pt}$

Formatted: Font: Times New Roman, 12 pt, Complex Script Font: $12 \mathrm{pt}$

Deleted: \& other authors

Formatted: Font: Times New Roman, 12 pt, Complex Script Font: $12 \mathrm{pt}$

Deleted: II

Deleted: If

Deleted: II

Deleted: II 
Shea, J. E., Hensel, M., Gleeson, C. \& Holden, D. W. (1996). Identification of a virulence locus encoding a second type III secretion system in Salmonella typhimurium. Proceedings of the National Academy of Sciences U S A, 93, $2593-2597$.

Shea, J. E., Beuzon, C. R., Gleeson, C., Mundy, R. \& Holden, D. W. (1999). Influence of the Salmonella typhimurium pathogenicity island 2 type III secretion system on bacterial growth in the mouse. Infection and Immunity, 67, 213-219.

Smith, H. W. \& Tucker, J. F. (1975). The effect of antibiotic therapy on the faecal excretion of Salmonella typhimurium by experimentally infected chickens. Journal of Hygiene (London), 75, 275-292.

Turner, A. K., Lovell, M. A., Hulme, S. D., Zhang-Barber, L. \& Barrow, P. A. (1998). Identification of Salmonella typhimurium genes required for colonization of the chicken alimentary tract and for virulence in newly hatched chicks. Infection and Immunity, 66, 2099-2106.

Wallis, T. S., Wood, M., Watson, P., Paulin, S., Jones, M. \& Galyov, E. (1999). Sips, Sops, and SPIs but not stn influence Salmonella enteropathogenesis. Advances in Experimental Medical Biology, 473, 275-280.

Wallis, T. S. \& Galyov, E. E. (2000). Molecular basis of Salmonella-induced enteritis. Molecular Microbiology, 36, 997-1005.

Wigley, P., Jones, M. A. \& Barrow, P. A. (2002). Salmonella enterica serovar Pullorum requires the Salmonella pathogenicity island 2 type III secretion system for virulence and carriage in the chicken. Avian Pathology $231,501-$ 506. 
Withanage, G. S., Kaiser, P., Wigley, P. Powers, C., Mastroeni, P., Brooks, H., _ _ _ _ - ', Roman, 12 pt, Complex Script Font: Barrow, P., Smith, A., Maskell, D. \& McConnell, I. (2004). Rapid expression of chemokines and proinflammatory cytokines in newly hatched chickens infected with Salmonella enterica serovar Typhimurium. Infection and Immunity, 72, 2152-2159. $12 \mathrm{pt}$

Formatted: Font: Times New Roman, 12 pt, Complex Script Font: $12 \mathrm{pt}$

Deleted: \& other authors

Formatted: Font: Times New Roman, 12 pt, Complex Script Font: $12 \mathrm{pt}$

Deleted: II

Formatted: Font: Times New Roman, 12 pt, Complex Script Font: $12 \mathrm{pt}$

Withanage, G. S., Wigley, P., Kaiser, P., Mastroeni, P., Brooks, H., Powers, C., Formatted: Font: Times New Beal, R., Barrow, P., Maskell, D. \& McConnell, I. (2005). Cytokine and chemokine responses associated with clearance of a primary Salmonella

Deleted: \& other authors Formatted: Font: Times New enterica serovar Typhimurium infection in the chicken and in protective immunity to rechallenge. Infection and Immunity, 73, 5173-5182. Roman, 12 pt, Complex Script Font: $12 \mathrm{pt}$

Deleted: II

Wood, M. W., Jones, M. A., Watson, P. R., Siber, A. M., McCormick, B. A.,

Hedges, S., Rosqvist, R., Wallis, T. S. \& Galyov, E. E. (2000). The secreted effector protein of Salmonella dublin, SopA, is translocated into eukaryotic cells and influences the induction of enteritis. Cellular Microbiology, 2, 293303. 


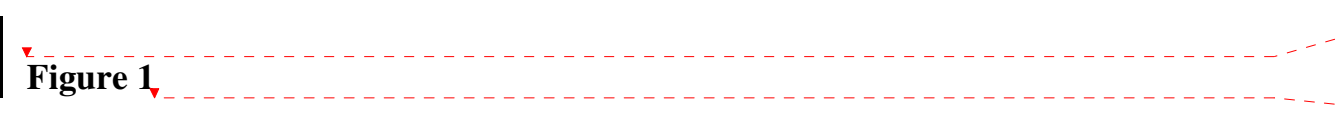

Deleted: $\mathbb{I}$

II

Deleted:

Recovery of $S_{-}$Typhimurium F98 and spaS $(S P I 1)$ and ssaU $(S P I 2)$ mutants

Formatted: Font: Italic

following oral experimental infection of one-day old Rhode Island Red chicks with

$10^{8} \mathrm{CFU}$. Viable counts of Salmonella expressed as CFU/g ( \pm SEM) in the liver (a)

Formatted: Font: Italic

Formatted: Font: Italic

Formatted: Font: Italic

Formatted: Font: Italic and caecal contents (b) were determined on Brilliant Green Agar on samples obtained at post mortem.

\section{Figure 2}

Recovery of $S_{-}$Typhimurium F98 and spaS (SPI1) and ssaU (SPI2) mutants following oral experimental infection of one-week old Rhode Island Red chicks with $10^{8}$ CFU,_after administration of an adult gut flora at one-day of age. Viable counts of Salmonella expressed as CFU/g ( \pm SEM) in the liver (a) and caecal

Formatted: Font: Italic

Formatted: Font: Italic

Formatted: Font: Italic

Formatted: Font: Italic

Formatted: Font: Italic contents (b) were determined on Brilliant Green Agar on samples obtained at post mortem. 
a
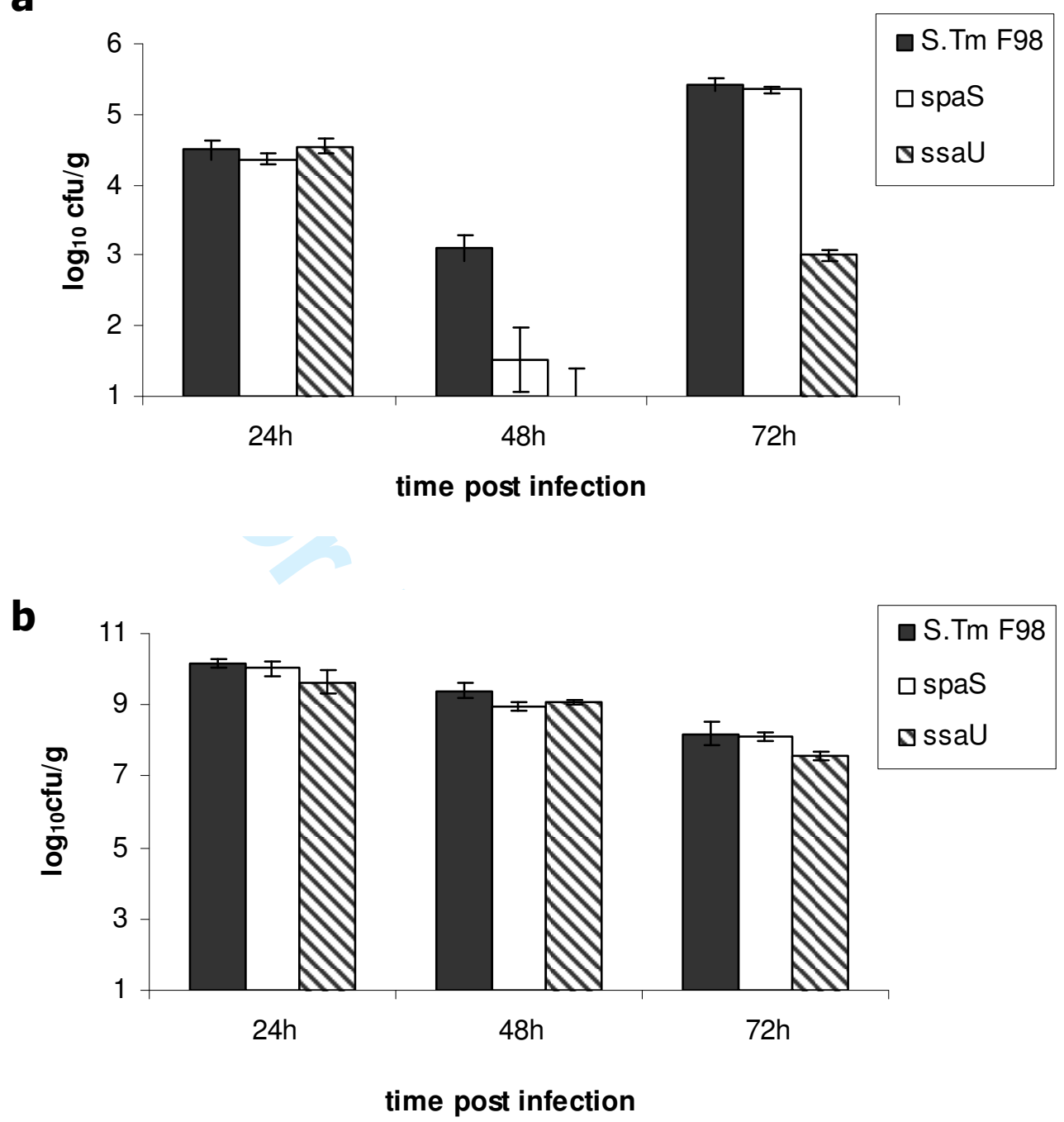
a

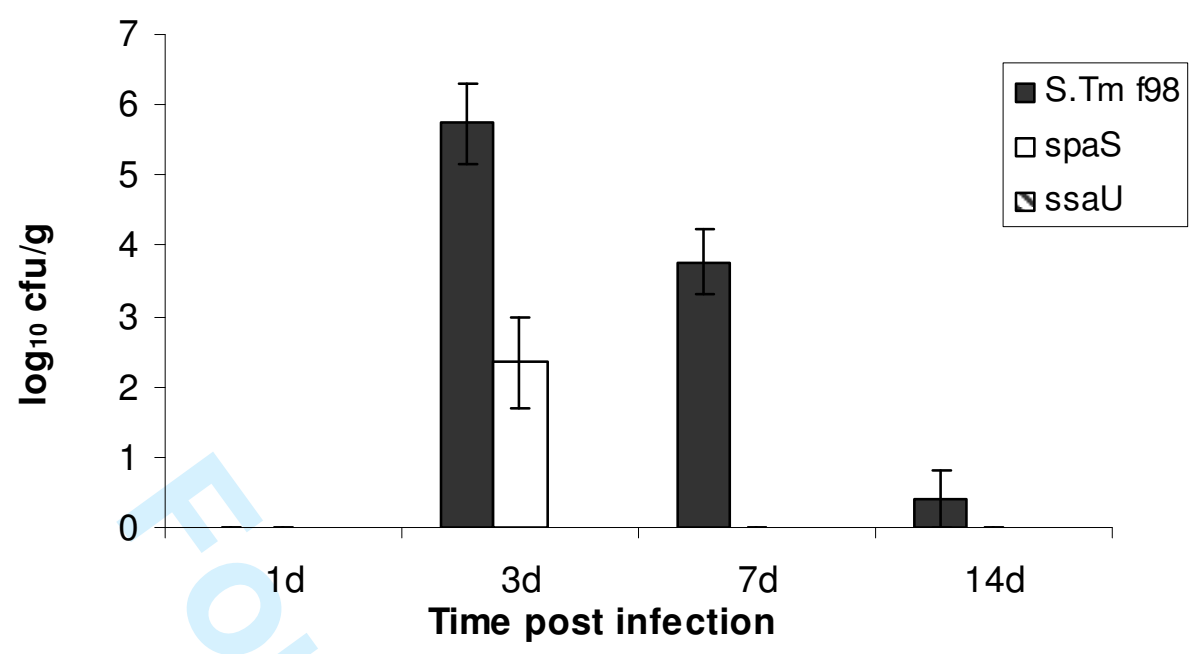

b

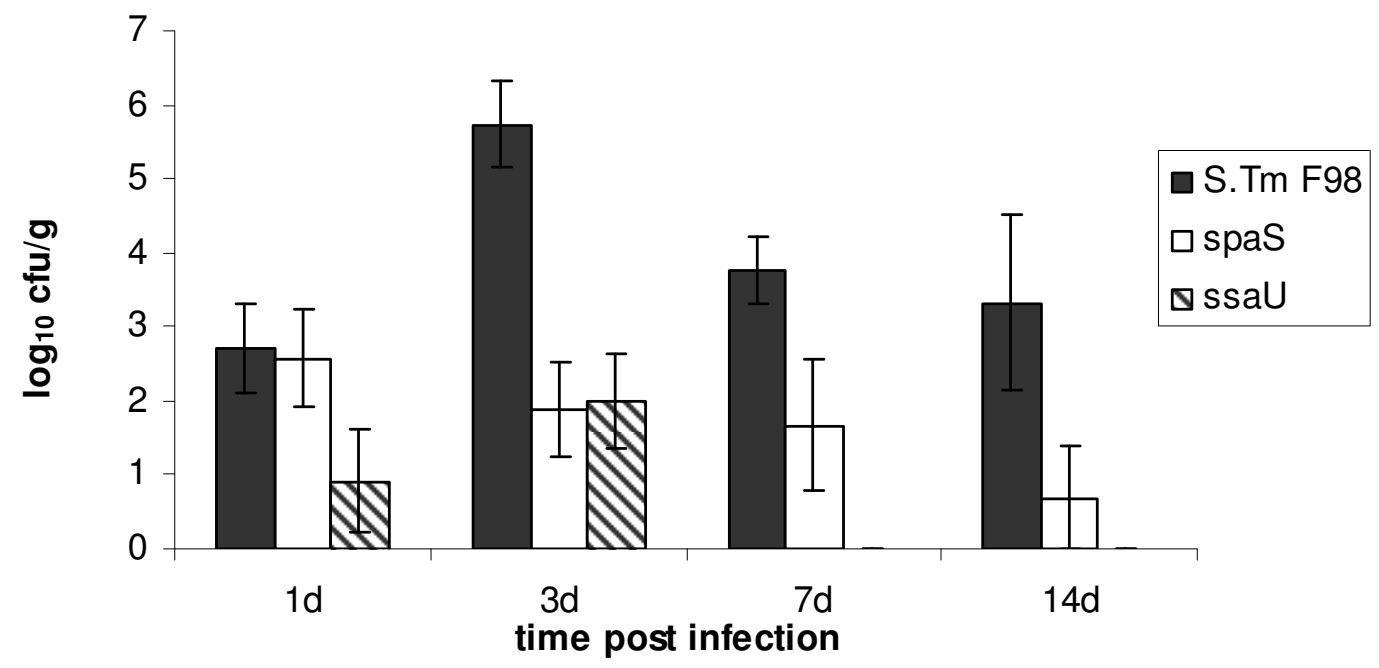

